\title{
Partial Agonists of the $\alpha 3 \beta 4 *$ Neuronal Nicotinic Acetylcholine Receptor Reduce Ethanol Consumption and Seeking in Rats
}

\author{
Susmita Chatterjee', Pia Steensland ${ }^{2}$, Jeffrey A Simms', Joan Holgate', Jotham W Coe ${ }^{3}$, Raymond S Hurst ${ }^{3}$, \\ Christopher L Shaffer ${ }^{3}$, John Lowe ${ }^{3}$, Hans Rollema*,3 and Selena E Bartlett*, \\ 'Ernest Gallo Clinic and Research Center, University of California San Francisco, Emeryville, CA, USA; ${ }^{2}$ Department of Clinical Neuroscience, \\ Karolinska Institutet, Stockholm, Sweden; ${ }^{3}$ Department of Neuroscience, Pfizer Global Research and Development, Groton, CT, USA
}

\begin{abstract}
Alcohol use disorders (AUDs) impact millions of individuals and there remain few effective treatment strategies. Despite evidence that neuronal nicotinic acetylcholine receptors ( $\mathrm{nAChRs}$ ) have a role in AUDs, it has not been established which subtypes of the nAChR are involved. Recent human genetic association studies have implicated the gene cluster CHRNA3-CHRNA5-CHRNB4 encoding the $\alpha 3$, $\alpha 5$, and $\beta 4$ subunits of the $\mathrm{nAChR}$ in susceptibility to develop nicotine and alcohol dependence; however, their role in ethanol-mediated behaviors is unknown due to the lack of suitable and selective research tools. To determine the role of the $\alpha 3$, and $\beta 4$ subunits of the nAChR in ethanol self-administration, we developed and characterized high-affinity partial agonists at $\alpha 3 \beta 4$ nAChRs, CP-60।932, and PF-4575/80. Both CP-601932 and PF-4575I80 selectively decrease ethanol but not sucrose consumption and operant selfadministration following long-term exposure. We show that the functional potencies of CP-60।932 and PF-4575। 80 at $\alpha 3 \beta 4$ nAChRs correlate with their unbound rat brain concentrations, suggesting that the effects on ethanol self-administration are mediated via interaction with $\alpha 3 \beta 4 \mathrm{nAChRs}$. Also varenicline, an approved smoking cessation aid previously shown to decrease ethanol consumption and seeking in rats and mice, reduces ethanol intake at unbound brain concentrations that allow functional interactions with $\alpha 3 \beta 4$ nAChRs. Furthermore, the selective $\alpha 4 \beta 2 * \mathrm{nAChR}$ antagonist, $\mathrm{DH} \beta \mathrm{E}$, did not reduce ethanol intake. Together, these data provide further support for the human genetic association studies, implicating CHRNA3 and CHRNB4 genes in ethanol-mediated behaviors. CP-601932 has been shown to be safe in humans and may represent a potential novel treatment for AUDs.
\end{abstract}

Neuropsychopharmacology (201I) 36, 603-6I5; doi:10.1038/npp.2010.191; published online 3 November 2010

Keywords: $\alpha 3 \beta 4$ * nicotinic acetylcholine receptor; ethanol; drug abuse; addiction; rat

\section{INTRODUCTION}

Alcohol and nicotine addiction are often treated as separate disorders, although $\sim 60-80 \%$ of heavy drinkers smoke tobacco (Moss et al, 2007), and it has been suggested that common genes are involved in the susceptibility of both alcohol and nicotine dependence (Dani and Harris, 2005; de Fiebre and Collins, 1992; Joslyn et al, 2008; Kamens et al, 2010; Schlaepfer et al, 2008). Additionally, it has been shown that ethanol can directly or indirectly interact with neuronal nicotinic acetylcholine receptors (nAChRs)

\footnotetext{
* Correspondence: Dr H Rollema, Department of Neuroscience, MS 8220-4159, Pfizer Global Research and Development, Groton, CT 06340, USA, Tel: + I 860 44I 6374, Fax: + I 860715 8375, E-mail: hans.rollema@pfizer.com or Dr SE Bartlett, Ernest Gallo Clinic and Research Center, University of California San Francisco, 5858 Horton Street, Suite 200, Emeryville, CA 94608, USA, Tel: + I 510 985 3133, Fax: + I 5 I0 985 310 I, E-mail: selenab@gallo.ucsf.edu Received 26 May 20I0; revised 3 September 2010; accepted 23 September 2010
}

(Blomqvist et al, 1992; Davis and de Fiebre, 2006; Le et al, 2000), which have been identified as important therapeutic targets for the treatment of alcohol use disorders (AUDs) (Chatterjee and Bartlett, 2010).

The nAChRs are well-characterized pentameric ligandgated ion channels consisting of different homomeric and heteromeric combinations of $\alpha 2-\alpha 10$ and $\beta 2-\beta 4$ subunits. The $\alpha 4, \beta 2$, and $\alpha 7$ subunits of the nAChRs have been shown to be most widely expressed in the brain, forming functional receptor subtypes either as heteromeric $\left(\alpha 4^{\star}\right.$ and $\left.\beta 2^{\star}\right)$ or homomeric $(\alpha 7)$ receptors $(*$ indicates the possibility of additional subunits). The $\alpha 2, \alpha 3, \alpha 6, \beta 2, \beta 3$, or $\beta 4$ subunits can combine to form either simple subtypes, such as $\alpha 3 \beta 4$, or complex native nAChRs, such as $\alpha 3 \beta 2 \beta 4^{*}$ or $\alpha 3 \beta 3 \beta 4^{*}$ and are localized in different brain regions and have specific functions (Gotti et al, 2006, 2007).

The $\alpha 4 \beta 2^{*} \mathrm{nAChR}$ is the predominant $\mathrm{nAChR}$ subtype in the brain, and it is now well established that it has an essential role in mediating nicotine's rewarding properties (Picciotto et al, 1998; Tapper et al, 2004). Consistent with 
an important role of $\alpha 4 \beta 2 \mathrm{nAChRs}$ in nicotine addiction, a recently introduced $\alpha 4 \beta 2 \mathrm{nAChR}$ partial agonist, varenicline (Coe et al, 2005a), has been demonstrated to be an efficacious smoking cessation aid in the clinic (Cahill et al, 2009). The subunit composition involved in ethanol's rewarding properties, however, remains controversial. It has been previously shown that varenicline reduces ethanol consumption and operant self-administration following long-term ethanol exposure in rats (Steensland et al, 2007) and mice (Kamens et al, 2010). This has since been supported by a clinical study showing that varenicline decreased ethanol consumption in heavy drinking smokers (McKee et al, 2009).

Recent human genetic association studies have identified a genetic locus, encoding for the $\alpha 3$ (CHRNA3), $\alpha 5$ (CHRNA5), and $\beta 4$ (CHRNB4) nAChR subunits in nicotine and alcohol-dependent subjects (Joslyn et al, 2008; Saccone et al, 2009; Wang et al, 2009), suggesting an involvement of these specific subunits in alcohol dependence. It has been difficult to determine the precise role of the individual subunits of the nAChR, as there have been few brain penetrant selective ligands that target the $\alpha 3 \beta 4$-containing nAChRs. In this study, we identified two nAChR ligands, CP-601932 and PF-4575180 (Figure 1), that are partial agonists at the $\alpha 3 \beta 4 \mathrm{nAChR}$ in order to determine the role of the $\alpha 3 \beta 4 \mathrm{nAChRs}$ in ethanol-mediated behaviors. CP-601932 has also high affinity for $\alpha 4 \beta 2$ nAChR and has been in development as a smoking cessation aid. It is an enantiomer derived from a racemic compound that was previously reported to be a potent, partial agonist at human $\alpha 4 \beta 2 \mathrm{nAChRs}$ expressed in oocytes (Coe et al, 2005b). The rat pharmacokinetic properties of CP-601932 have been described (Shaffer et al, 2009). PF-4575180 was synthesized during studies on [3.2.1]azabicyclic compounds that are selective for $\alpha 3 \beta 4$ and nAChRs comprising an $\alpha 6 / \alpha 4$ chimera combined with the $\beta 4$ subunit $(\alpha 6 / 4 \beta 4)$, but have relatively low affinity for $\alpha 7, \alpha 4 \beta 2$, and $\alpha 1$-containing nAChRs (Lowe et al, 2010). The data presented here on these compounds and on varenicline suggest that $\alpha 3 \beta 4^{*}$ nAChRs could have an important role in ethanol-mediated behaviors.
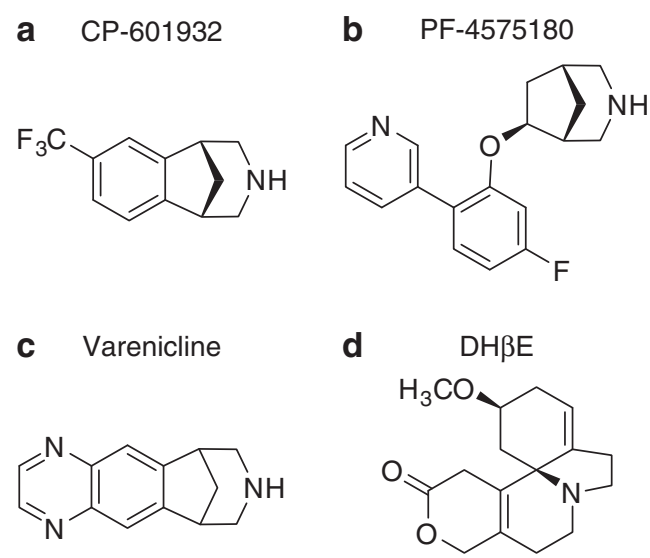

Figure I Structures of (a) CP-601932, (b) PF-4575 I80, (c) varenicline, and (d) dihydro- $\beta$-erythroidine.

\section{MATERIALS AND METHODS}

\section{Animals and Housing}

Adult, male Wistar rats (Harlan, Indianapolis, IN), a strain traditionally used for ethanol-intake studies, including in our previous publications (Simms et al, 2008; Steensland et al, 2007), were used for alcohol-intake studies at the Gallo Center. Adult male Sprague-Dawley rats (Charles River, Wilmington, MA), the same strain as used in previous pharmacokinetic and pharmacodynamic studies (Rollema et al, 2010; Shaffer et al, 2009), were used for pharmacokinetic studies at Pfizer Global Research and Development. Rats were individually housed in climate-controlled rooms and kept on a 12-h reversed light-dark cycle (lights off at 1000 hours), and food and water were available ad libitum. All procedures were preapproved by the Gallo Center and Pfizer Institutional Animal Care and Use Committees and were in accordance with the NIH guidelines for the Humane Care and Use of Laboratory Animals.

\section{Pharmacodynamic Studies}

In vitro binding affinity to $n A C h R s$. Binding affinities of the test compounds to nAChR subtypes were determined as described (Rollema et al, 2007), using $\left[{ }^{3} \mathrm{H}\right]$ epibatidine to label $\alpha 4 \beta 2$ and $\alpha 3 \beta 4 \mathrm{nAChRs}$ expressed in HEK293 cells. $K_{\mathrm{i}}$ values were calculated according to $K_{\mathrm{i}}=\mathrm{IC}_{50} /\left(1+\left[{ }^{3} \mathrm{H}\right]\right.$ ligand) $/ K_{\mathrm{d}}$ ) and expressed as $K_{\mathrm{i}}$.

In vitro functional activity at $\alpha 3 \beta 4$ and $\alpha 4 \beta 2 n A C h R s$ expressed in HEK cells by FLIPR. Agonist and antagonist activities were assessed using HEK293 cell lines stably transfected with either human $\alpha 3 \beta 4$ or $\alpha 4 \beta 2$ nAChRs. Functional activity was measured as agonist-evoked calcium flux assay on a Fluorescence Imaging Plate Reader (FLIPR, Molecular Devices, Silicon Valley, CA), as previously described (Wishka et al, 2006). On the day of the assay, the cells were loaded with a $1: 1$ mixture of $2 \mu \mathrm{M}$ Calcium Green-1, AM (Molecular Probes) dissolved in anhydrous DMSO, and 20\% pluronic F-127 (Molecular Probes). This solution was added directly to the growth media of each well to achieve a final concentration of $2 \mu \mathrm{M}$ of Calcium Green-1. Plates were then loaded onto the FLIPR and read at excitation and emission wavelengths of 488 and $516 \mathrm{~nm}$, respectively. Agonist testing was done by measuring the effect of a single addition of test compound to the medium in comparison with the effect of $100 \mu \mathrm{M}$ ACh. To assess inhibitory activities, test compounds were applied to cells for $2 \mathrm{~min}$ and subsequently challenged with $30 \mu \mathrm{M}$ ACh. Inhibition for each concentration of the test compounds was calculated from the change in fluoresce $(\Delta \mathrm{F})$ evoked by $30 \mu \mathrm{M} \mathrm{ACh}$ in wells pretreated with the test compound relative to the $\Delta \mathrm{F}$ of wells that were pretreated with vehicle. Each experiment was run in quadruplicate, and $\mathrm{EC}_{50}$ and $\mathrm{IC}_{50}$ values were estimated from the concentration-activation and concentration-inhibition curves. The fraction of activated $\alpha 3 \beta 4 \mathrm{nAChRs}$ was calculated from the compound's instantaneous activation and inhibition concentration response. This fraction was derived from the product of the equations for the fraction of ACh-evoked current: $E_{\max } \times\left(C /\left(C+E_{50}\right)\right.$ and for the fraction of 
receptors that are available to be activated (ie, the fraction not inhibited) at that concentration: $100-\left\{100 \times\left(C /\left(C+\mathrm{IC}_{50}\right)\right\}\right.$.

\section{Pharmacokinetic Studies}

All pharmacokinetic and tissue binding studies were performed in Sprague-Dawley rats, or with tissues derived from them using standard procedures and a characterized LC-MS/MS assay to determine the estimates of unbound brain concentrations after each dose (details are given in Supplementary Information).

\section{Ethanol-Intake Studies}

Operant self-administration procedures. Operant selfadministration testing was conducted in standard operant conditioning chambers (Coulbourn Instruments, Allentown, PA) as described previously (Steensland et al, 2007). In brief, rats were randomly divided into two groups each for CP-601932 (ethanol group: $n=13$; sucrose group: $n=10$ ) and PF-4575180 compound testing (ethanol group: $n=8$; sucrose group: $n=14$ ). Rats were trained to self-administer $10 \%$ ethanol $(\mathrm{v} / \mathrm{v})$ or $5 \%$ sucrose, on a fixed ratio 3 (three active lever presses required for $0.1 \mathrm{ml}$ reward) schedule of reinforcement, daily (Monday through Friday) for $30 \mathrm{~min}$. To evaluate the acute effects, CP-601932 (5 and $10 \mathrm{mg} / \mathrm{kg}$ subcutaneously (s.c.)) or vehicle (saline) were administered $30 \mathrm{~min}$ before the operant session (mean body weight before treatment: ethanol group: $550 \pm 11 \mathrm{~g}$; sucrose group: $596 \pm 12 \mathrm{~g} ; 11$ weeks; $\sim 55$ sessions). In a separate group of rats, PF-4575180 ( 1 and $10 \mathrm{mg} / \mathrm{kg}$ s.c.) or vehicle (saline) was administered $2 \mathrm{~h}$ before the operant session (mean body weight before treatment: ethanol group: $580 \pm 16 \mathrm{~g}$; sucrose group: $534 \pm 9 \mathrm{~g} ; 10$ weeks; $\sim 50$ sessions). We found no effect of PF-4575180 when administered 30 min prior to the operant session and hence switched to administering $2 \mathrm{~h}$ prior. Each injection was given 7 days apart in a Latin square design, thus each animal served as its own control. Between the injection days, the rats were exposed to their normal schedule of reinforcement as described above, with no injections for the remaining days of that week.

To evaluate the effect of chronic/multiple administration of CP-601932 on operant self-administration of ethanol, rats were trained to self-administer $10 \%(\mathrm{v} / \mathrm{v})$ ethanol as described above. CP-601932 (10 mg/kg s.c.) or vehicle (saline) was administered 30 min before the operant ethanol self-administration session on each of 5 consecutive days (Monday through Friday), and the number of lever presses was recorded each day. The post-treatment baseline active lever presses was recorded on the Saturday, $24 \mathrm{~h}$ following the last CP-601932 administration. It has previously been shown that the changing of the home cage results in decreased activity during the self-administration session (Balcombe et al, 2004). Thus, the data from the operant self-administration session following a cage change (day 3 ) were excluded from the analysis, as the results could not be attributed to the CP-601932 treatment.

Intermittent-access two-bottle-choice drinking paradigm. The intermittent-access 20\% ethanol two-bottle-choice drinking paradigm has been described previously
(Simms et al, 2008; Wise, 1973), and details are given in the Supplementary Information. For the intermittent-access $5 \%$ sucrose two-bottle-choice drinking paradigm, the rats were given access to $5 \%$ sucrose rather than $20 \%$ ethanol. Drug administration began after the rats had maintained stable baseline drinking levels of the $20 \%(\mathrm{v} / \mathrm{v})$ ethanol solution or $5 \%$ sucrose. In the ethanol-intake studies, CP$601932(1,5$, and $10 \mathrm{mg} / \mathrm{kg}$ s.c.) or vehicle (saline), dihydro$\beta$-erythroidine $(\mathrm{DH} \beta \mathrm{E})$ (6 and $10 \mathrm{mg} / \mathrm{kg}$ s.c.) or vehicle (saline), PF-4575180 (1 and $10 \mathrm{mg} / \mathrm{kg}$ s.c.) or vehicle (saline) were administered to three separate groups of rats (CP601932: $n=12,6 \pm 1 \mathrm{~g} / \mathrm{kg} / 24 \mathrm{~h}, 11$ weeks; $\sim 33$ drinking sessions; $\mathrm{DH} \beta \mathrm{E}: n=12,5.1 \pm 0.4 \mathrm{~g} / \mathrm{kg} / 24 \mathrm{~h}, 12$ weeks; $\sim 36$ sessions; PF-4575180: $n=10,6.1 \pm 0.3 \mathrm{~g} / \mathrm{kg} / 24 \mathrm{~h}, 9$ weeks; $\sim 27$ session). The mean body weight of the rats at the first CP-601932, DH $\beta$ E, and PF-4575180 treatment were $539 \pm 18$, $576 \pm 21$, and $493 \pm 9 \mathrm{~g}$, respectively. Administration of CP$601932(1,5$, and $10 \mathrm{mg} / \mathrm{kg}$ s.c.) and PF-4575180 (1 and $10 \mathrm{mg} / \mathrm{kg}$ s.c.) for the sucrose consuming groups began once the animals had attained stable drinking levels (CP-601932 group: $n=10,25 \pm 2 \mathrm{~g} / \mathrm{kg} / 24 \mathrm{~h}, 8$ weeks; 24 sessions; PF4575180 group: $n=10,27 \pm 2 \mathrm{~g} / \mathrm{kg} / 24 \mathrm{~h}, 11$ weeks; 33 sessions). The mean body weights of the rats at the first CP-601932 and PF-4575180 treatment in the sucrose groups were $444 \pm 16$ and $486 \pm 20 \mathrm{~g}$, respectively. All the treatments were administered $30 \mathrm{~min}$ before the presentation of either the water or $20 \%$ ethanol or $5 \%$ sucrose bottles. Each injection was given 7 days apart using a Latin square design, thus each animal served as its own control. Between the injection days, the rats were exposed to their normal drinking schedule of intermittent access as described above with no injections for the remaining days of that week.

Taste preference. To control for the modulation of taste sensitivity, CP-601932 (10 mg/kg s.c.) and PF- 4575180 $(10 \mathrm{mg} / \mathrm{kg}$ s.c.) were administered to two separate groups of rats that had access to water or to a solution containing saccharin $(0.2 \%)$ with quinine $(0.001 \%)$ (Cippitelli et al, 2010; Goodwin and Amit, 1998) instead of $20 \%$ ethanol in the two-bottle-choice intermittent-access drinking paradigm. The bottles were measured at $30 \mathrm{~min}, 6$, and $24 \mathrm{~h}$ after the fluids were presented, and measurements were taken to the nearest gram. The taste preference of saccharin with quinine over water (the ratio of saccharin with quinine to total fluid intake) was calculated at each time point (CP-601932 group: $n=5,4 \pm 0.6 \mathrm{mls} / 30 \mathrm{~min}, 5$ weeks; 15 sessions, average weight: $396 \pm 9 \mathrm{~g}$; PF-4575180 group: $n=5$, $5.5 \pm 1 \mathrm{mls} / 30 \mathrm{~min}, 5$ weeks; 15 sessions, average weight: $404 \pm 10 \mathrm{~g}$ ). All treatments were administered $30 \mathrm{~min}$ before the presentation of either the water or saccharin/quinine bottles. Each injection was given 5 days apart using a Latin square design; thus, each animal served as its own control. Between the injection days, the rats were exposed to their normal drinking schedule of intermittent access as described above with no injections for the remaining days of that week.

\section{Drugs and Chemicals}

Ethanol and sucrose solutions were prepared in filtered water using 95\% (v/v) ethanol (Gold Shield Chemical Ac., Hayward, CA) and sucrose (Fisher Scientific, 
Pittsburgh, PA), respectively. Radioligands were purchased from PerkinElmer Life and Analytical Sciences (Boston, MA) CP-601932 [(1S,5R)-2,3,4,5-tetrahydro-7-(trifluoromethyl)-1,5-methano-1H-3-benzazepine] and PF-4575180 [ rac-exo-[6-(2-(pyridin-3-yl)-5-fluorophenoxy))]-3-azabicyclo [3.2.1] octane dihydrochloride salt] were synthesized at Pfizer Global Research and Development, Groton, CT (for a description of the synthesis of PF-4575180, see Supplementary Information). $\mathrm{DH} \beta \mathrm{E}$ was purchased from Sigma (St Louis, MO). All drugs were dissolved in saline and administered s.c. in a volume of $1 \mathrm{ml} / \mathrm{kg}$. All drug solutions were prepared immediately before each injection.

\section{Statistics}

Statistical analysis was performed using Graph Pad Prism (Graph Pad, San Diego, CA) or Sigma Stat (Systat Software, San Jose). Behavioral data from acute treatment in the operant self-administration and two-bottle-choice paradigms were analyzed using repeated measures one-way ANOVA followed by Newman-Keuls post hoc analysis when a significant overall main effect was found $(P<0.05)$. The taste preference data were analyzed using paired $t$-tests, with a significance level of $P<0.05$. The blood-ethanol concentration (BEC) and chronic treatment data were analyzed with two-way ANOVA followed by Newman-Keuls post hoc analysis when a significant overall main effect was found $(P<0.05)$.

\section{RESULTS}

\section{In Vitro Pharmacodynamics of CP-601932 and PF-4575180}

We measured binding affinities and functional activities of CP-601932 and PF-4575180 in HEK293 cells expressing either $\alpha 3 \beta 4$ or $\alpha 4 \beta 2$ nAChRs (Table 1). The averaged concentration-dependent inhibition and activation curves at $\alpha 3 \beta 4$ are shown in Figure 2 and for $\alpha 4 \beta 2$ nAChRs are shown in the Supplementary Information (Supplementary Figure S1), with inserts showing free brain concentrations and the fraction of the nAChR subtype that is inhibited and activated (see below). CP-601932 has the same high-binding affinity at $\alpha 3 \beta 4 \quad\left(K_{\mathrm{i}}=21 \mathrm{nM}\right)$ as at $\alpha 4 \beta 2 \mathrm{nAChRs}$ $\left(K_{\mathrm{i}}=21 \mathrm{nM}\right)$ and an order of magnitude lower affinity for $\alpha 6$ and $\alpha 7 \mathrm{nAChR}$ subtypes $\left(K_{\mathrm{i}}>300 \mathrm{nM}\right)$. Functional activity was measured using a $\mathrm{Ca}^{2+}$-sensitive dye in a cell-based fluorescence assay. Relative to ACh, CP-601932 is a partial agonist of $\alpha 3 \beta 4 \mathrm{nAChRs}$, with an $\mathrm{EC}_{50}$ of about $3 \mu \mathrm{M}$ and intrinsic efficacy of about $30 \%$ of that of ACh. CP-601932 produced no measurable change in $\mathrm{Ca}^{2+}$ fluorescence when applied to HEK293 cells expressing $\alpha 4 \beta 2$ nAChRs (Supplementary Figure S1A). When preapplied to cells expressing either $\alpha 3 \beta 4$ or $\alpha 4 \beta 2$ nAChRs, CP-601932 inhibited the $\mathrm{Ca}^{2+}$ signal evoked by a subsequent challenge with $\mathrm{ACh}$, with $\mathrm{IC}_{50}$ values of 257 and $114 \mathrm{nM}$, respectively. A likely explanation for the inhibition of the ACh-evoked response is that, like other agonists of nAChRs, CP-601932 can stabilize the desensitized conformation of the receptors and thus prevent subsequent activation by ACh (for review, see Ochoa et al (1989)). However, further studies on the mechanism of inhibition of expressed receptors by the test compounds were not performed.

PF-4575180 is one of a series of compounds that bind to $\alpha 3^{*}$ and $\alpha 6^{*}$ nAChRs, but have very low affinity for $\alpha 7$ nAChR (Lowe et al, 2010). PF-4575180 was found to have 10 times higher affinity for $\alpha 3 \beta 4 \mathrm{nAChRs}\left(K_{\mathrm{i}}=4.2 \mathrm{nM}\right)$ than for $\alpha 6 / 4 \beta 4 \mathrm{nAChRs}\left(K_{\mathrm{i}}=45 \mathrm{nM}\right)$ and very low affinity for $\alpha 4 \beta 2 \mathrm{nAChRs}\left(K_{\mathrm{i}}>1.2 \mu \mathrm{M}\right)$. The intrinsic agonist efficacy of PF-4575180 is $52 \%$ relative to $\mathrm{ACh}$ at $\alpha 3 \beta 4 \mathrm{nAChRs}$, but PF-4575180 produces no measurable activation of $\alpha 4 \beta 2$ nAChRs as measured by $\mathrm{Ca}^{2+}$-evoked fluorescence (Supplementary Figure S1B). PF-4575180 is also more potent at inhibiting $\alpha 3 \beta 4\left(\mathrm{IC}_{50}=112 \mathrm{nM}\right)$ than $\alpha 4 \beta 2$

Table I Binding Affinities, Functional Potencies, and Intrinsic Efficacies vs Ach of CP-601932, PF-4575I 80, and Varenicline at Human $\alpha 3 \beta 4$ and $\alpha 4 \beta 2$ nAChRs Subtypes Expressed in HEK293 Cells

\begin{tabular}{|c|c|c|c|c|c|}
\hline \multirow{3}{*}{ Compound } & \multirow{3}{*}{ nAChR Subtype } & \multirow{3}{*}{$\begin{array}{l}\text { Binding affinity } \\
\qquad K_{\mathrm{i}}(\mathrm{n} M)\end{array}$} & \multicolumn{3}{|c|}{ Function potency and efficacy } \\
\hline & & & \multicolumn{2}{|c|}{ Activation } & \multirow{2}{*}{$\begin{array}{l}\text { Inhibition } \\
I C_{50}(n M)\end{array}$} \\
\hline & & & $E C_{50}(\mu M)$ & Efficacy (\% vs ACh) & \\
\hline \multirow[t]{2}{*}{ CP-601932 } & $\alpha 3 \beta 4$ & $21 \pm 28(13)$ & $2.92 \pm 0.32(3)$ & $30.2 \pm 3.4(3)$ & $257 \pm 41(3)$ \\
\hline & $\alpha 4 \beta 2$ & $21 \pm 19(13)$ & $>30(3)$ & a & $114 \pm 29(3)$ \\
\hline \multirow[t]{2}{*}{ PF-4575 I 80} & $\alpha 3 \beta 4$ & $4.2 \pm 0.9(4)$ & $0.24 \pm 0.05$ & $52.4 \pm 3(4)$ & $112 \pm 25(4)$ \\
\hline & $\alpha 4 \beta 2$ & $>1195 \pm 475(4)^{b}$ & $>30(4)$ & a & $733 \pm 190(4)$ \\
\hline \multirow[t]{2}{*}{ Varenicline } & $\alpha 3 \beta 4$ & $74.7 \pm 6.2(18)$ & $1.84 \pm 0.58(5)$ & $93.5 \pm 1.4(5)$ & $220 \pm 1.4(5)$ \\
\hline & $\alpha 4 \beta 2$ & $0.3 \pm 0.02(18)$ & $1.4 \mid \pm 0.17(5)$ & $32.4 \pm 1.1(5)$ & $0.23 \pm 0.03(5)$ \\
\hline \multirow[t]{2}{*}{$\mathrm{DH} \beta \mathrm{E}$} & $\alpha 3 \beta 4$ & & & $0^{c}$ & $23000^{b}$ \\
\hline & $\alpha 4 \beta 2$ & & & $0^{c}$ & $370^{b}$ \\
\hline
\end{tabular}

Data are expressed as mean \pm SEM $(n)$.

antrinsic efficacy could not be determined due to insufficient signal amplitude at the highest test concentration.

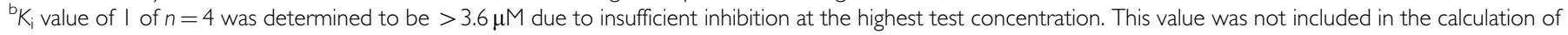
mean and SEM.

${ }^{c}$ Antagonist, data are from Harvey et al (1996). 
nAChRs $\left(\mathrm{IC}_{50}=733 \mathrm{nM}\right)$. For comparison, binding and functional data for varenicline at $\alpha 3 \beta 4$ and $\alpha 4 \beta 2 \mathrm{nAChRs}$ (Rollema et al, 2007), as well as reported $\mathrm{IC}_{50}$ values of $\mathrm{DH} \beta \mathrm{E}$ for antagonism of $\alpha 4 \beta 2$ and $\alpha 3 \beta 4 \mathrm{nAChRs}$ (Harvey et al, 1996), are also included in Table 1.
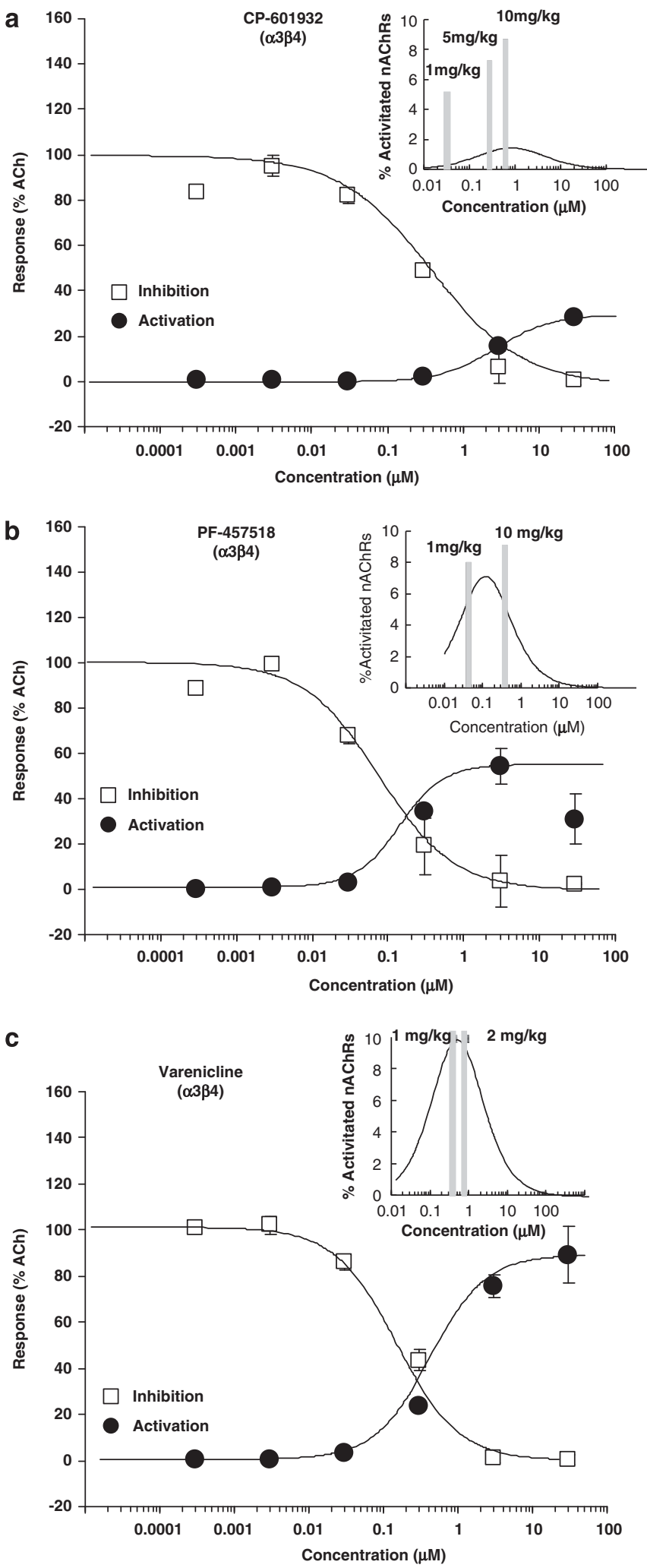

In Vivo Pharmacokinetics of CP-601932 and PF-4575180

Time courses of unbound brain compound concentrations $\left(C_{\mathrm{b}, \mathrm{u}}\right)$ (see Supplementary Information) after s.c. doses that have been used for the behavioral studies are shown in Figure 3. CP-601932 readily penetrates the CNS and at $30 \mathrm{~min}$ reaches maximal $C_{\mathrm{b}, \mathrm{u}}$ values of $340 \mathrm{nM}$ after $5 \mathrm{mg} / \mathrm{kg}$ and $710 \mathrm{nM}$ after $10 \mathrm{mg} / \mathrm{kg}$. Brain concentrations of CP601932 decline very slowly and levels stay relatively high, eg, $530 \mathrm{nM}$ at $5 \mathrm{~h}$ and $85 \mathrm{nM}$ at $24 \mathrm{~h}$ after $10 \mathrm{mg} / \mathrm{kg}$ (Figure 3a). PF-4571580 also rapidly reaches its highest $C_{\mathrm{b}, \mathrm{u}}$ of 55 and $550 \mathrm{nM}$ after 1 and $10 \mathrm{mg} / \mathrm{kg}$, respectively, but levels decline rapidly and are $<1$ and $5 \mathrm{nM}$ at $6 \mathrm{~h}$ after 1 and $10 \mathrm{mg} / \mathrm{kg}$, respectively (Figure $3 \mathrm{~b}$ ).

\section{In Vivo Ethanol-Intake Studies}

To evaluate the effect of CP-601932 on ethanol selfadministration, the compound was given to a group of Wistar rats that were trained to self-administer $10 \%$ ethanol as previously described (Steensland et al, 2007). CP-601932 (5 and $10 \mathrm{mg} / \mathrm{kg}$ s.c.) or vehicle was administered $30 \mathrm{~min}$ before the start of the operant session. CP-601932 treatment had an overall main effect on operant self-administration of $10 \%$ ethanol $(\mathrm{F}(2,12)=9.1, P<0.01)$. Post hoc analysis revealed that the highest dose of CP-601932 $(10 \mathrm{mg} / \mathrm{kg})$ significantly decreased the number of presses on the active lever and inhibited $10 \%$ ethanol self-administration compared with active lever presses for vehicle treatment (Figure 4a), with no overall main effect on the number of inactive lever presses, see Supplementary Table S1 (Supplementary Information). To determine whether CP-601932's effect in decreasing ethanol self-administration behavior was specific, CP-601932 was given to a separate group of rats trained to self-administer $5 \%$ sucrose (see Materials and Methods). CP-601932 treatment did not have an overall main effect on $5 \%$ sucrose self-administration $(\mathrm{F}(2,9)=0.19$, n.s.; Figure $4 \mathrm{~b})$. We also found no effect on the number of presses on the inactive lever, see Supplementary Table S1. These results suggest that CP-601932 selectively decreases ethanol self-administration by modulating the reinforcing properties of ethanol without affecting natural reward seeking behavior.

We have previously shown that the $20 \%$ ethanol intermittent-access two-bottle-choice drinking paradigm induces high voluntary ethanol intake in rats (Simms et al, 2008; Steensland et al, 2007). We examined the effect of CP-601932 (1, 5, and $10 \mathrm{mg} / \mathrm{kg}$ s.c.) or vehicle using this

Figure 2 Concentration-dependent activation and inhibition curves of

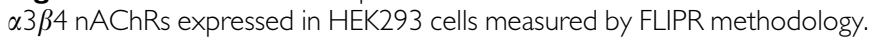
Activation data (filled circles) are expressed as fraction of the response evoked by $100 \mu \mathrm{M}$ ACh. Inhibition data (open squares) were generated by applying $30 \mu \mathrm{M}$ ACh in the presence of varying concentrations of the test compound, and the data are normalized to the response evoked by $30 \mu \mathrm{M}$ $\mathrm{ACh}$ in the absence of test compound. The activation and inhibition curves are the curves of best fit through the data points. (Inserts) Concentrationdependent fraction of activated $\alpha 3 \beta 4 \mathrm{nAChRs}$ calculated from the fitted activation and inhibition curves. Vertical gray bars correspond to the estimated unbound rat brain concentrations (in $\mathrm{nM}$ ) measured at $30 \mathrm{~min}$ after 5 and $10 \mathrm{mg} / \mathrm{kg}$ of CP-601932 (a), I and $10 \mathrm{mg} / \mathrm{kg}$ of PF-4575 I 80 (b), and $\mathrm{I}$ and $2 \mathrm{mg} / \mathrm{kg}$ of varenicline (c). 
a
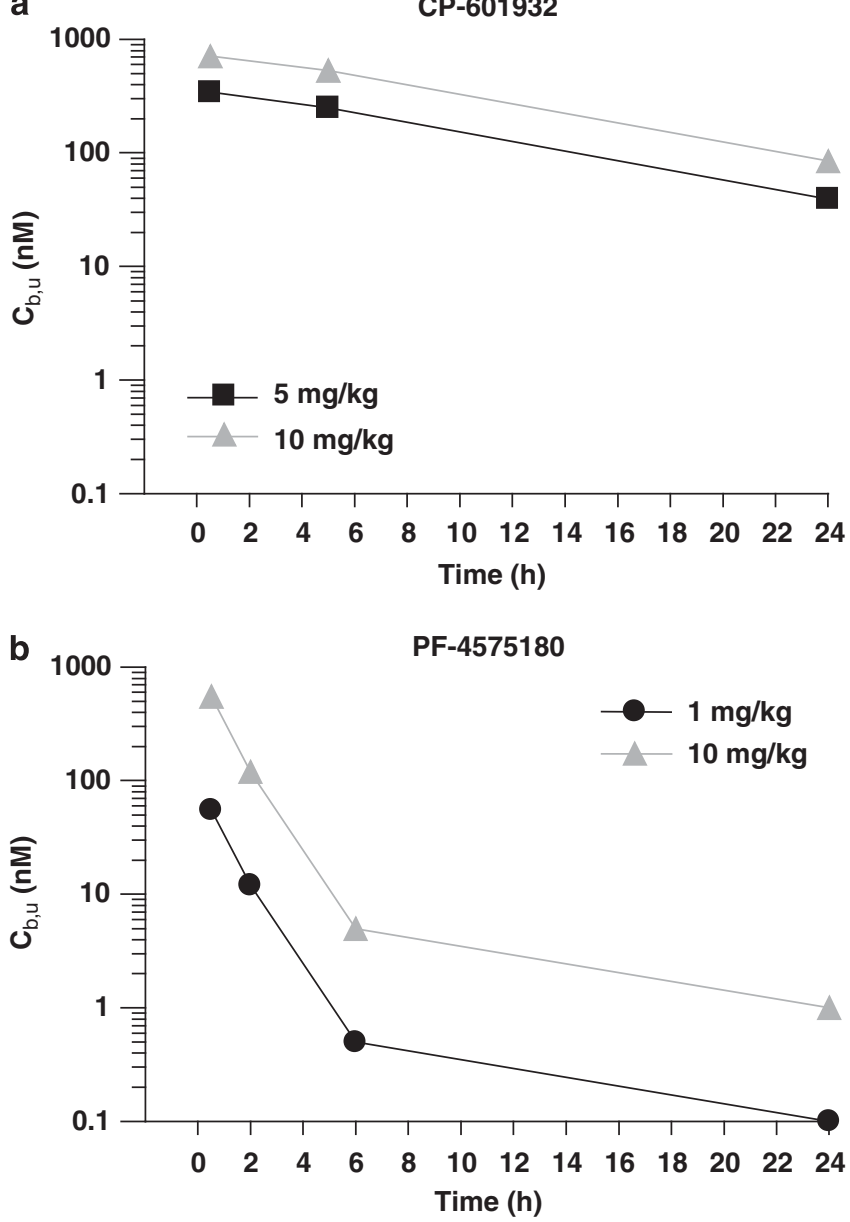

Figure 3 Time courses of unbound CP-601932 and PF-4575।80 concentrations in rat brain $\left(C_{\mathrm{b}, \mathrm{u}}\right)$ after s.c. administration of $5 \mathrm{mg} / \mathrm{kg}$ (-口) and $10 \mathrm{mg} / \mathrm{kg}(\boldsymbol{\Delta}-\mathbf{\Delta}) \mathrm{CP}-601932$ (a) and $1 \mathrm{mg} / \mathrm{kg}$ (-) and $10 \mathrm{mg} / \mathrm{kg}(\mathbf{\Delta}-\mathbf{\Delta})$ PF-4575 I 80 (b). Data are expressed as nM $(n=2)$.

paradigm once the rats had maintained stable baseline drinking (see Materials and Methods). There was an overall main effect of CP-601932 treatment on ethanol consumption at all time points examined separately (30 min: $\mathrm{F}(3,11)=14, P<0.001 ; 6 \mathrm{~h}: \mathrm{F}(3,11)=19.8, P<0.001$; and 24 h: $\mathrm{F}(3,11)=17.3, P<0.001)$. Post hoc analysis shows that both 5 and $10 \mathrm{mg} / \mathrm{kg}$ CP-601932 significantly decreased ethanol consumption at $30 \mathrm{~min}$ (Figure $4 \mathrm{c}$ ), but only the highest CP-601932 dose $(10 \mathrm{mg} / \mathrm{kg})$ decreased ethanol consumption at the 6-h (Supplementary Table S2) and 24-h (Supplementary Table S2) time points. Furthermore, there was an overall main effect of CP-601932 on the preference of ethanol over water at all time points $(30 \mathrm{~min}$ : $\mathrm{F}(3,11)=7.6, P<0.001$ (data not shown); $6 \mathrm{~h}: \mathrm{F}(3,11)=7.8$, $P<0.001 ; 24 \mathrm{~h}: \mathrm{F}(3,11)=11.5, P<0.0001$; Supplementary Table S2). Post hoc analysis shows that the highest dose of CP-601932 decreased the preference for ethanol over water at all time points (Supplementary Table S2). In contrast, CP-601932 treatment did not have an overall main effect on water consumption or the total fluid intake at any time point (Supplementary Table S2). To further evaluate the specificity of its effect on high ethanol intake, CP-601932 was administered to a group of rats consuming high amounts of $5 \%$ sucrose using the intermittent-access drinking paradigm (see Materials and Methods). CP601932 treatment did not have an overall main effect on sucrose consumption at any of the measured time points examined separately ( 30 min: $\mathrm{F}(3,10)=1$, n.s.; Figure $4 \mathrm{~d}$; $6 \mathrm{~h}: \mathrm{F}(3,10)=3$, n.s.; Supplementary Table S2; and $24 \mathrm{~h}$ : $\mathrm{F}(3,10)=1$, n.s.; Supplementary Table S2). Similarly, there was no overall main effect of CP-601932 on the preference of sucrose over water (Supplementary Table S2; Supplementary Information). These results show that CP-601932 selectively reduces ethanol consumption without having any significant effect on water or sucrose consumption in rats. We also examined the possibility that CP-601932 decreases ethanol intake by affecting BEC (Supplementary Table S3; Supplementary Information). We found no difference in the BECs between a vehicle and CP-601932-treated group, suggesting that CP-601932 is reducing ethanol consumption by directly affecting the reinforcing properties of ethanol.

\section{The $\alpha 3 \beta 4^{\star}$ nAChR Partial Agonist PF-4575180, Selectively Decreases Ethanol Self-administration and Voluntary Ethanol Consumption}

As CP-601932 has a similar affinity at $\alpha 3 \beta 4$ and $\alpha 4 \beta 2$ nAChRs, a partial agonist at $\alpha 3 \beta 4$ nAChRs, PF-4575180, was used to distinguish between the role of $\alpha 3 \beta 4^{*}$ and $\alpha 4 \beta 2^{*}$ nAChRs in ethanol-mediated effects. PF-4575180 is a partial agonist at $\alpha 3 \beta 4 \mathrm{nAChRs}$ (Table 1) and is tested using the self-administration and intermittent-access two-bottle-choice drinking paradigms. Unlike CP-601932, PF-4575180 ( 1 and $10 \mathrm{mg} / \mathrm{kg}$ s.c.) or vehicle was given $2 \mathrm{~h}$ and not $30 \mathrm{~min}$ before the start of the operant session (see Materials and Methods). We found no effect when administering $30 \mathrm{~min}$ prior to the operant session. We speculate that it could be due to complex PK/PD relationships in vivo, such as a possible active metabolite; however, this remains to be investigated. PF- 4575180 treatment had an overall main effect on operant selfadministration of $10 \%$ ethanol $(\mathrm{F}(2,7)=4.6, \quad P<0.05)$. Post hoc analysis revealed that the highest dose of PF$4575180 \quad(10 \mathrm{mg} / \mathrm{kg})$ significantly decreased the number of presses on the active lever and inhibited $10 \%$ ethanol self-administration compared with active lever presses for vehicle treatment (Figure 5a). Furthermore, PF- 4575180 had no overall main effect on the number of presses on the inactive lever, see Supplementary Table S1 (Supplementary Information). To evaluate the specificity of PF-4575180 in decreasing ethanol administration, it was given to another group of rats self-administering $5 \%$ sucrose (see Materials and Methods). PF-4575180 treatment did not have an overall main effect on $5 \%$ sucrose self-administration $(\mathrm{F}(2,13)=0.22$, n.s.; Figure $5 \mathrm{~b})$ or have any effect on the number of presses on the inactive lever (Supplementary Table S1). These results indicate that PF-4575180, similar to CP-601932, selectively decreases ethanol seeking without affecting sucrose-seeking behavior.

We also evaluated the effect of PF-4575180 on voluntary excessive ethanol consumption using the intermittentaccess two-bottle-choice paradigm as previously described (Simms et al, 2008). PF-4575180 ( 1 and $10 \mathrm{mg} / \mathrm{kg}$ ) or vehicle (saline) was given when the rats had attained stable baseline drinking levels. There was an overall main effect of 
Operant self-administration drinking paradigm
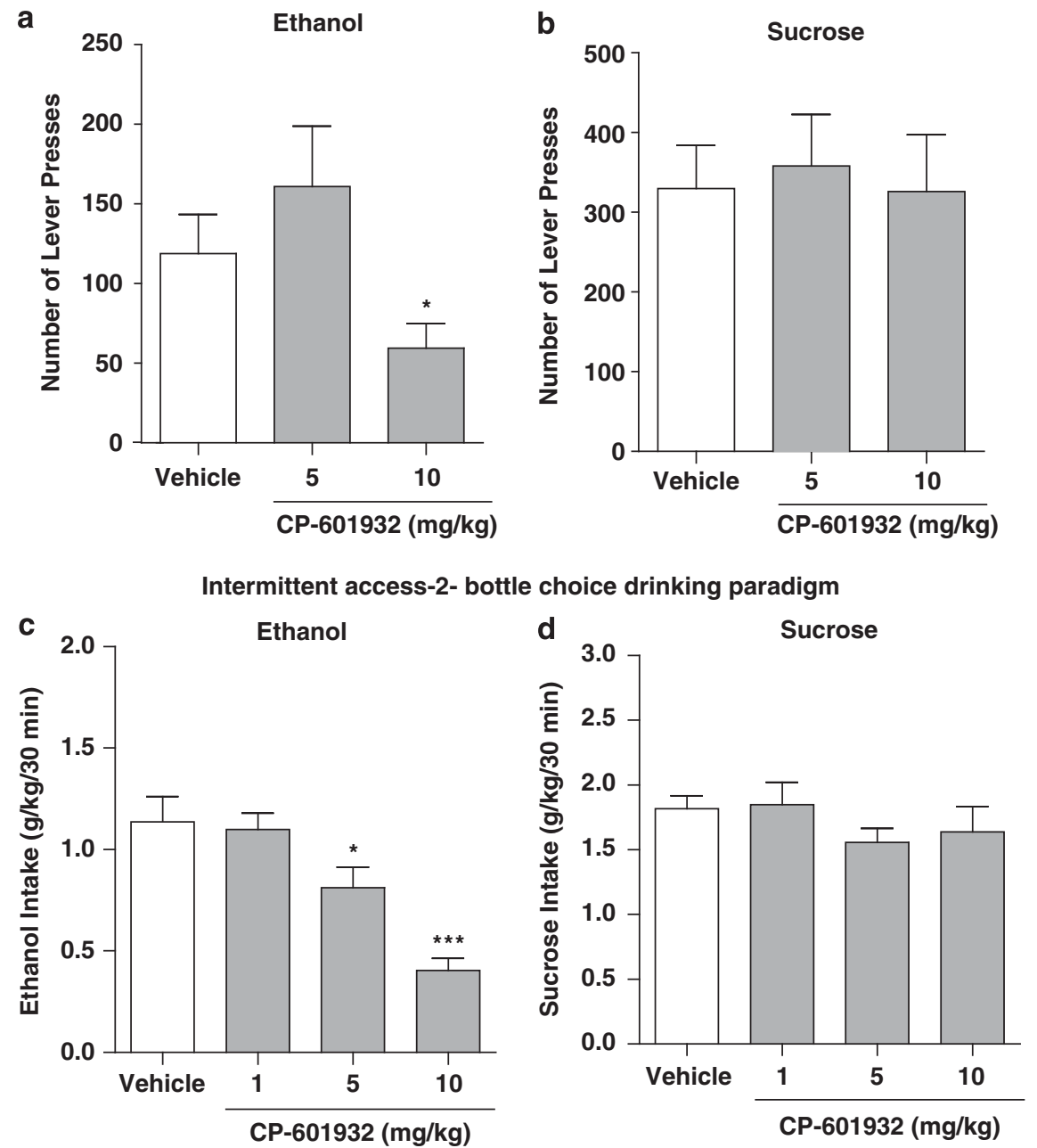

Figure 4 Acute administration of CP-601932 decreases ethanol but not sucrose consumption and seeking. CP-601932 (I0 mg/kg) decreased active lever presses for (a) 10\% ethanol, but not (b) $5 \%$ sucrose in the operant self-administration paradigm. CP-601932 (5 and $10 \mathrm{mg} / \mathrm{kg})$ significantly decreased high voluntary ethanol consumption (c) but not sucrose consumption (d) at 30 min after the onset of drinking in rats using the intermittent-access two-bottlechoice drinking paradigm. All values are expressed as mean number of active lever presses \pm SEM $(a, b)$ and mean ethanol or sucrose intake $(g / k g) \pm S E M$ (c, d) (repeated measures ANOVA followed by Newman-Keuls post hoc test. $* P<0.05$ compared with vehicle, $n=10-13$ for the operant paradigm and $* P<0.05$, **** $P<0.00$ I compared with vehicle, $n=10-12$ for the two-bottle-choice paradigm.

PF-4575180 treatment on ethanol consumption at all time points examined separately $(30 \mathrm{~min}: \quad \mathrm{F}(2,9)=13.8$, $P<0.0001 ; \quad 6 \mathrm{~h}: \quad \mathrm{F}(2,9)=64.6, \quad P<0.0001 ; \quad$ and $24 \mathrm{~h}$ : $\mathrm{F}(2,9)=29, P<0.0001)$. Post hoc analysis shows that only the highest dose of PF-4575180 (10 mg/kg s.c.) decreased ethanol consumption at $30 \mathrm{~min}$ (Figure $5 \mathrm{c}$ ), whereas both doses of PF-4575180 (1 and $10 \mathrm{mg} / \mathrm{kg}$ s.c.) decreased ethanol consumption at the 6-h (Supplementary Table S4) and 24-h time points (Supplementary Table S4). Furthermore, there was an overall main effect of PF-4575180 on the preference of ethanol over water at all time points $(30 \mathrm{~min}: \mathrm{F}(2,9)=5.9$, $P<0.05 ; 6 \mathrm{~h}: \mathrm{F}(2,9)=33, P<0.0001$; and $24 \mathrm{~h}: \mathrm{F}(2,9)=31$, $P<0.0001)$. Post hoc analysis shows that the highest dose of PF-4575180 $(10 \mathrm{mg} / \mathrm{kg})$ decreased the preference for ethanol over water at the 30 -min time point and 24 -h time point, whereas both doses 1 and $10 \mathrm{mg} / \mathrm{kg}$ of PF-4575180 decreased the preference at the 6-h time point (Supplementary Table S4). In contrast to CP-601932, PF-4575180 treatment showed an overall main effect on water consumption at the 6- and 24-h time points (30 min: $\mathrm{F}(2,9)=2.7$, n.s.; 6 h: $\mathrm{F}(2,9)=4.6, P<0.05$, Supplementary Table S4; and $24 \mathrm{~h}: \mathrm{F}(2,9)=13.4, P<0.001)$. Post hoc analysis revealed that only the highest dose of PF-4575180 $(10 \mathrm{mg} / \mathrm{kg})$ increased water consumption at the 6- and 24-h time points (Supplementary Table S4). However, PF-4575180's increase in water consumption does not affect the total fluid consumption at any time point (Supplementary Table S4). Similar to CP-601932, we evaluated the selectivity of PF-4575180 in decreasing ethanol consumption using $5 \%$ sucrose intermittent-access paradigm. PF-4575180 treatment did not have an overall main effect on sucrose consumption at any of the measured time points examined separately (30 min: $\mathrm{F}(2,9)=0.0009$, n.s.; Figure 5d; $6 \mathrm{~h}: \mathrm{F}(2,9)=1.6$, n.s.; Supplementary Table S4; and $24 \mathrm{~h}: \mathrm{F}(2,9)=0.27$, n.s.; Supplementary Table S4). Similarly, there was no overall main effect of PF-4575180 on the preference of sucrose over water (Supplementary Table S4). These results show that PF-4575180 with 

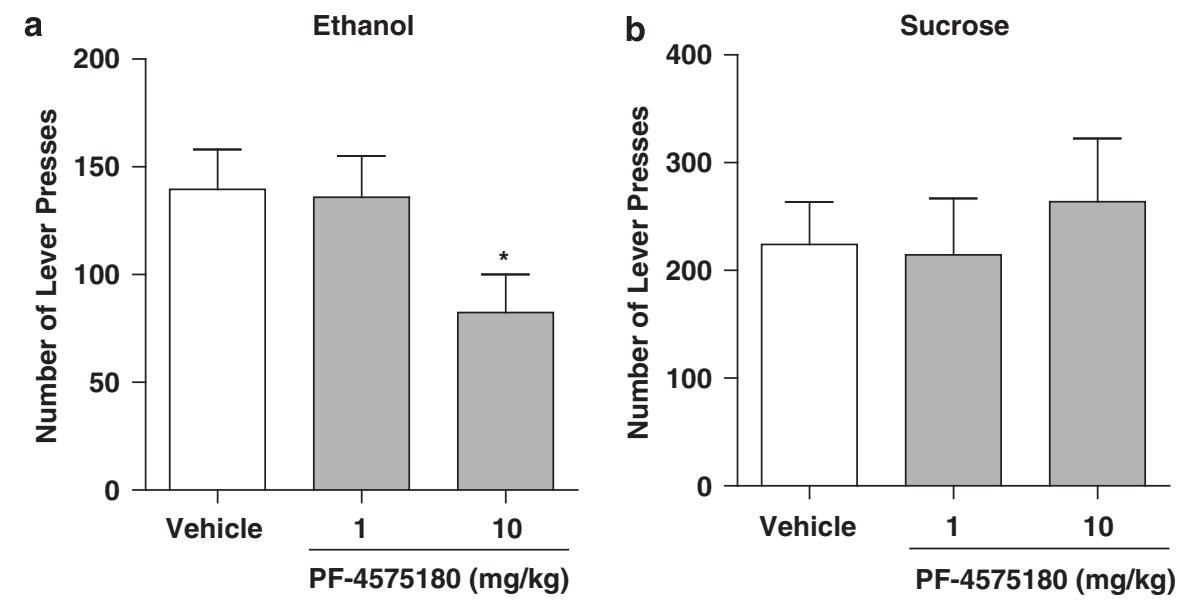

Intermittent access- 2-bottle choice drinking paradigm
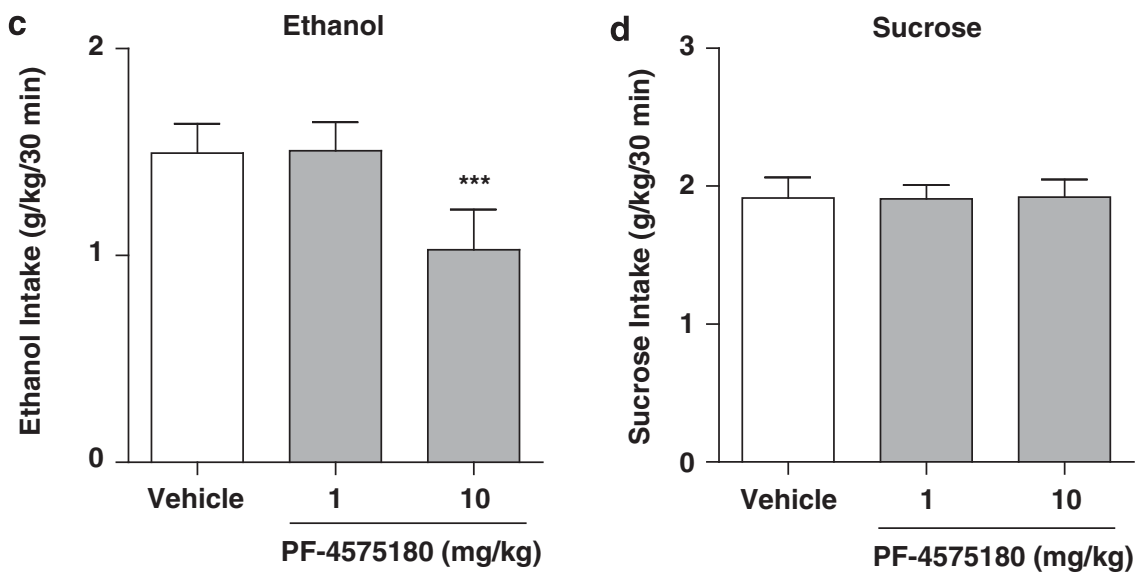

Figure 5 PF-4575/80, an $\alpha 3 \beta 4$ partial agonist, decreased ethanol but not sucrose consumption and seeking. PF-4575/80 (I 0 mg/kg s.c.) treatment decreased active lever presses for ethanol (a) but not for $5 \%$ sucrose self-administration (b) in the operant drinking paradigm. PF-4575। 80 (I0 mg/kg s.c.) treatment decreased voluntary ethanol consumption (c) but not sucrose consumption (d) 30 min after the onset of drinking in the intermittent-access twobottle-choice drinking paradigm. The values are expressed as mean number of active lever presses $\pm \mathrm{SEM}(\mathrm{a}, \mathrm{b})$ or ethanol or sucrose intake $(\mathrm{g} / \mathrm{kg}) \pm \mathrm{SEM}$ (c, d) (repeated measures ANOVA followed by Newman-Keuls post hoc test). $*<<0.05$, compared with vehicle, $n=8-14$ for the operant paradigm and **** $P<0.001$ compared with vehicle, $n=10$ for the two-bottle-choice paradigm.

preference for the $\alpha 3 \beta 4 \mathrm{nAChR}$ selectively reduces ethanol consumption without having any significant effect on sucrose consumption in rats. However, in contrast to CP-601932 treatment, PF-4575180 increases water consumption but without affecting the total fluid intake.

\section{PF-4575180 and CP-601932 do not Affect Taste Preference for Saccharin with Quinine}

As PF-4575180 treatment decreased ethanol intake while increasing water consumption, we evaluated whether this effect could be due to a shift in the preference from ethanol to water by interacting with the taste of ethanol. Hence, we assessed the effect of both PF-4575180 $(10 \mathrm{mg} / \mathrm{kg})$ and CP-601932 $(10 \mathrm{mg} / \mathrm{kg})$ in two separate groups of rats that were voluntarily consuming a solution of $0.2 \%$ saccharin with $0.001 \%$ quinine in the intermittent-access drinking paradigm (see Materials and Methods). There was no effect of PF-4575180 treatment on saccharin/quinine taste preference and consumption measured at all the time points, examined separately using $t$-test (saccharin/quinine preference: $30 \mathrm{~min}: t=0.4, \mathrm{df}=4, P=$ n.s.; $6 \mathrm{~h}: t=1.6$, $\mathrm{df}=4, P=$ n.s.; and $24 \mathrm{~h}: t=1.6, \mathrm{df}=4, P=$ n.s. (Table 2); consumption (mls): 30 min: $t=0.02, \mathrm{df}=4, P=$ n.s.; $6 \mathrm{~h}$ : $t=0.3, \mathrm{df}=4, P=$ n.s.; and $24 \mathrm{~h}: t=0.79, \mathrm{df}=4, P=$ n.s. (Table 2)). CP-601932 treatment had no effect on the taste preference of saccharin/quinine at any time point (saccharin/quinine preference: $30 \mathrm{~min}: t=0.6, \mathrm{df}=4, P=\mathrm{n} . \mathrm{s} . ; 6 \mathrm{~h}$ : $t=1.2, \mathrm{df}=4, P=$ n.s.; and $24 \mathrm{~h}: t=0.97, \mathrm{df}=4, P=$ n.s. (Table 2)). It had no effect on the saccharin/quinine consumption at both $30 \mathrm{~min}$ and $6 \mathrm{~h}$, but had an effect only at the 24-h time point (saccharin/quinine consumption (mls): 30 min: $t=1.5, \mathrm{df}=4, P=$ n.s.; $6 \mathrm{~h}: t=2.6, \mathrm{df}=4$, $P=$ n.s.; and $24 \mathrm{~h}: t=5, \mathrm{df}=4, P<0.01$ (Table 2)). Both CP-601932 and PF-4575180 do not modulate the taste preference for saccharin/quinine solution. Hence, although PF-4575180 increases water consumption, it most likely does not shift the preference of ethanol to water. 
Table 2 CP-601932 and PF-4575 I80 Treatment has no Effect on Taste Preference of Saccharin/Quinine Solution Using the Intermittent Access Two-Bottle-Choice Drinking Paradigm

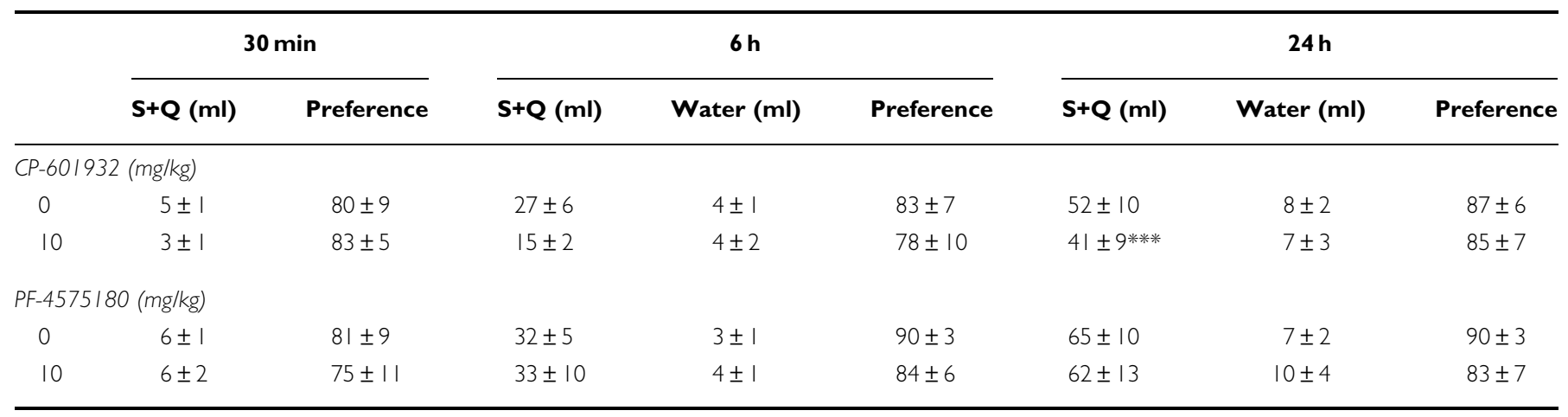

Data are expressed as mean \pm SEM (paired t-test). ${ }^{* * *} P<0.01$.

\section{Effect of Repeated Administrations of CP-601932 on Ethanol Intake}

CP-601932 has been shown to be safe in humans, and as it could have beneficial effects in human subjects with AUDs using a chronic treatment regimen, we evaluated whether repeated administration of CP-601932 would also suppress ethanol consumption without any subsequent rebound increase in drinking in rats. Vehicle or CP-601932 $(10 \mathrm{mg} /$ $\mathrm{kg}$ s.c.) were given for 5 consecutive days, once per day $30 \mathrm{~min}$ before the self-administration session in rats using the operant self-administration paradigm (see Materials and Methods). Once the rats had attained stable baseline active lever presses, they were randomly divided into two groups, CP-601932 (10 mg/kg s.c.) and vehicle (saline). We found that CP-601932, but not vehicle treatment, decreased ethanol operant self-administration on each of the 5 days. Two-way ANOVA analysis of active lever presses revealed a significant effect of treatment $(\mathrm{F}(1,64)=25, P<0.001)$ but no effect of day $(\mathrm{F}(4,64)=0.761$, n.s. $)$ and no interaction between treatment $\times$ day $(\mathrm{F}(4,64)=0.263$, n.s.). Post hoc analysis showed that CP-601932 significantly reduced the number of active lever presses during the treatment period (Figure 6). There was no rebound increase in active lever presses in comparison to baseline when the chronic CP-601932 treatment was terminated $(\mathrm{F}(3,22)=0.008$, n.s.). Furthermore, there was no overall main effect on the number of inactive lever responding of treatment $(\mathrm{F}(1,64)=0.3$, n.s. $)$, or day $(\mathrm{F}(4,64)=0.06$, n.s. $)$, or the interaction of treatment $\times$ day $(F(4,64)=0.08$, n.s. $)$. These results show that both acute and multiple administrations of CP-601932 selectively reduce ethanol self-administration in chronically exposed ethanol consuming rats without inducing a rebound increase in the ethanol self-administration after the cessation of the treatment. In addition, the active lever presses returned to pretreatment baseline drinking levels $24 \mathrm{~h}$ following the end of the treatment period.

\section{The $\alpha 4 \beta 2^{\star}$ nAChR Antagonist DH $\beta E$, does not Decrease Heavy Ethanol Consumption}

Considering the difference in in vitro activity of CP-601932 and PF-4575180 at nAChRs and the finding that both compounds effectively decrease ethanol consumption, it appears that $\alpha 4 \beta 2^{\star} \mathrm{nAChRs}$ have a minor role in

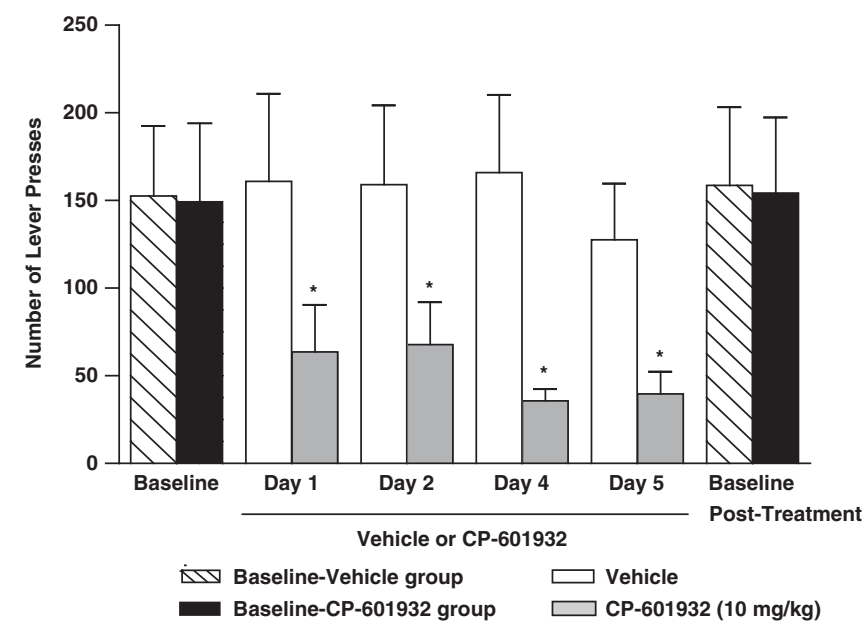

Figure 6 Multiple repeated administration of CP-601932 decreased ethanol consumption using the operant self-administration paradigm. Chronic administration of CP-601932 (10 mg/kg s.c.) but not vehicle decreased active lever presses for $10 \%$ ethanol. CP-60 I 932 ( 10 mg $/ \mathrm{kg}$ s.c.) or vehicle (saline s.c.) was administered on each of 5 consecutive days, $30 \mathrm{~min}$ before the start of the operant session. The values are expressed as ethanol intake $(\mathrm{g} / \mathrm{kg}) \pm \mathrm{SEM}$ (two-way ANOVA followed by NewmanKeuls post hoc test). $* P<0.05$ compared with vehicle, $n=6-7$.

ethanol-mediated behaviors. To confirm this hypothesis, the $\alpha 4 \beta 2^{*} \mathrm{nAChR}$ antagonist, $\mathrm{DH} \beta \mathrm{E}$, previously shown (Le et al, 2000) to have no effect in other ethanol-intake models, was examined in long-term drinking rats, using the intermittent-access two-bottle-choice paradigm model. We found that $\mathrm{DH} \beta \mathrm{E}$ does not affect ethanol consumption or preference in long-term heavy drinking rats (Supplementary Figure S2; Supplementary Table S5; Supplementary Information). The fact that both $\mathrm{CP}-601932$ and PF4575180 , but not $\mathrm{DH} \beta \mathrm{E}$, reduced ethanol consumption suggests that $\alpha 3 \beta 4^{\star}$, rather than $\alpha 4 \beta 2^{\star}$ nAChRs, have a primary role in the modulation of ethanol consumption in long-term heavy drinking rats.

\section{Correlation Between Effects on Ethanol Intake and nAChR Interactions}

To assess the functional interactions of PF-4575180 and CP-601932 with $\alpha 3 \beta 4^{*}$ nAChRs after doses administered in the ethanol-intake studies, we compared their $C_{\mathrm{b}, \mathrm{u}}$ values 
at $30 \mathrm{~min}$ after each dose with effects in the voluntary ethanol consumption model. By superimposing $C_{\mathrm{b}, \mathrm{u}}$ (bars in Figure 2 inserts) over the in vitro inhibition- and activation-concentration curves of $\alpha 3 \beta 4$ nAChRs (Figure 2), the extent of inhibition/activation of the $\alpha 3 \beta 4$ subtype can be estimated for each dose. The 5 and $10 \mathrm{mg} / \mathrm{kg}$ doses of CP601932, which both decrease ethanol intake, result in $C_{\mathrm{b}, \mathrm{u}}$ values that are close to the area of overlap between the $\alpha 3 \beta 4$ inhibition and activation curves, thought to represent a pharmacologically active range (Hogg and Bertrand, 2004). Taking into account that the majority of receptors will be inactivated, presumably via receptor desensitization, both doses are expected to result in sustained activation of a small fraction of $\alpha 3 \beta 4 \mathrm{nAChRs}$ (insert, Figure $2 \mathrm{a}$ ). PF-4575180 achieves $C_{\mathrm{b}, \mathrm{u}}$ values at $30 \mathrm{~min}$ after 1 and $10 \mathrm{mg} / \mathrm{kg}$ that can functionally interact with $\alpha 3 \beta 4 \mathrm{nAChRs}$ and both doses are predicted to produce sustained activation of a small portion of the $\alpha 3 \beta 4$ subtype (Figure 2b, insert). The finding that $10 \mathrm{mg} / \mathrm{kg}$, but not $1 \mathrm{mg} / \mathrm{kg}$ PF-4575180 was effective in reducing ethanol consumption $30 \mathrm{~min}$ after dosing was therefore unexpected and will be discussed below. At these $C_{\mathrm{b}, \mathrm{u}}, \mathrm{CP}-601932$ and PF-4575180 can partially inhibit, but not activate $\alpha 4 \beta 2$ nAChRs: CP-601932 acts as an $\alpha 4 \beta 2 \mathrm{nAChR}$ antagonist and PF-4575180 has relatively low affinity for $\alpha 4 \beta 2 \mathrm{nAChRs}$ (Supplementary Figure S1A and B).

A comparison of varenicline rat neuropharmacokinetic data (Rollema et al, 2009) with its functional potencies at $\alpha 3 \beta 4$ nAChRs (Table 1), demonstrates that doses of 1 and $2 \mathrm{mg} / \mathrm{kg}$ that were previously found to significantly reduce ethanol intake (Steensland et al, 2007), are associated with a sufficiently high $C_{\mathrm{b}, \mathrm{u}}$ to produce robust activation, as well as inhibition of $\alpha 3 \beta 4 \mathrm{nAChRs}$ (Figure 2c). As shown previously (Rollema et al, 2007, 2010), varenicline can potently interact with $\alpha 4 \beta 2$ nAChRs and at the $C_{\mathrm{b}, \mathrm{u}}$ achieved after 1 and $2 \mathrm{mg} / \mathrm{kg}$ it will mainly inhibit this subtype (Supplementary Figure S1C).

These results suggest that PF-4575180, CP-601932, and varenicline can reduce ethanol intake via partial inhibition of $\alpha 3 \beta 4^{*} \mathrm{nAChRs}$ and $\alpha 4 \beta 2^{*} \mathrm{nAChRs}$ and/or by sustained modest activation of $\alpha 3 \beta 4^{\star}$ nAChRs. Given the lack of effect of the $\alpha 4 \beta 2^{*} \mathrm{nAChR}$ antagonist $\mathrm{DH} \beta \mathrm{E}$, inhibition of $\alpha 4 \beta 2^{*}$ nAChRs alone is apparently not sufficient to suppress alcohol intake, which further supports a role for $\alpha 3 \beta 4$ nAChRs. Finally, an interesting finding is that all compounds are still active at $24 \mathrm{~h}$ after single doses and still reduce voluntary alcohol consumption at a time point when drug exposures have declined significantly.

\section{DISCUSSION}

Recent human genetic association studies suggest that the gene cluster CHRNA3-CHRNA5-CHRNB4, encoding the $\alpha 3, \alpha 5$, and $\beta 4$ subunits, is associated with both alcohol and nicotine dependence (Chen et al, 2009; Freathy et al, 2009; Joslyn et al, 2008). To investigate the role of $\alpha 3 \beta 4^{*}$ nAChRs in ethanol-mediated behaviors, we characterized the effects of two compounds, CP-601932 and PF-4575180, that are partial agonist at $\alpha 3 \beta 4$ nAChRs. CP-601932 is also a lowefficacy $\alpha 4 \beta 2 \mathrm{nAChR}$ partial agonist that has been clinically tested as a smoking cessation aid. It was generally well tolerated, but not further developed because of a moderate two fold increase in abstinence rate that was not statistically significant (Pfizer, data on file). PF-4575180 is a [3.2.1]azabicyclic analog (Lowe et al, 2010) that was found to bind with an order of magnitude higher affinity to $\alpha 3 \beta 4$ $\left(K_{\mathrm{i}}=4.2 \mathrm{nM}\right)$ than to $\alpha 6^{*} \mathrm{nAChRs}$ and to have very low affinity for $\alpha 4 \beta 2 \mathrm{nAChRs}\left(K_{\mathrm{i}}>1.2 \mu \mathrm{M}\right)$. We report here that both CP-601932 and PF-4575180 reduce ethanol selfadministration and consumption and have a long-lasting effect on ethanol-mediated behaviors, reducing the preference for ethanol consumption for up to $24 \mathrm{~h}$ with no effect on sucrose intake. PF-4575180, but not CP-601932, was found to also increase water consumption, in other words to shift the preference from ethanol to water. However, neither compound modulated the taste preference for saccharin-quinine solutions and hence do not interact with the taste of ethanol.

Active doses of CP-601932 result in $C_{\mathrm{b}, \mathrm{u}}$ that are predicted to activate, but not completely inhibit nAChRs and that represent a pharmacologically relevant concentration range (Hogg and Bertrand, 2004). Based on in vitro functional data $C_{\mathrm{b}, \mathrm{u}}$ of CP-601932 at active doses, it is predicted that a substantial portion of both $\alpha 4 \beta 2$ and $\alpha 3 \beta 4$ nAChRs would be inhibited and that a small portion of $\alpha 3 \beta 4 \mathrm{nAChRs}$ would also be persistently activated. The $\alpha 4 \beta 2 \mathrm{nAChRs}$ are predicted not to be activated in vivo, due to the very low (undetectable) intrinsic activity of CP-601932 at $\alpha 4 \beta 2$ nAChRs in vitro. It is important to note that this is also the case for the effects of the $\alpha 4 \beta 2 \mathrm{nAChR}$ partial agonist varenicline on ethanol-mediated behaviors. After doses of 1 and $2 \mathrm{mg} / \mathrm{kg}$ s.c., previously shown to significantly reduce ethanol consumption and self-administration in rats (Steensland et al, 2007), its rat $C_{\mathrm{b}, \mathrm{u}}$ is sufficiently high to also interact functionally with $\alpha 3 \beta 4 \mathrm{nAChRs}$ and to both partially activate and partially inhibit this subtype. We hypothesize that this combination of activities would lead to a low level of persistent channel activation in the brain at active doses. As expected, at these doses, varenicline almost completely inhibits its main target, the $\alpha 4 \beta 2 \mathrm{nAChR}$ subtype. Effects of the preferential $\alpha 3 \beta 4 \mathrm{nAChR}$ partial agonist PF-4575180 on ethanol consumption are probably predominantly mediated by activation and inhibition of $\alpha 3 \beta 4^{*} \mathrm{nAChRs}$, as its low-binding affinity for $\alpha 4 \beta 2 \mathrm{nAChRs}$ results in minimal inhibition of that subtype at the highest PF-4575180 dose.

One caveat is, however, that the in vitro pharmacology used in this assessment was determined with expressed human receptors, whereas the behavioral experiments were conducted in rats. In addition, the cells express an undefined stoichiometry of $\alpha$ and $\beta$ subunits, which can also influence receptor pharmacology (Nelson et al, 2003; Zhou et al, 2003). Therefore, although the conclusions described above are aligned with the in vitro pharmacology described in this work, potency differences between the in vitro systems used and native rat brain receptors could significantly influence the interpretation. Although both the 1 and $10 \mathrm{mg} / \mathrm{kg}$ doses are associated with initial PF-4575180 brain concentrations that can desensitize a large portion and activate a small fraction of $\alpha 3 \beta 4^{*}$ nAChRs, only $10 \mathrm{mg} / \mathrm{kg}$ PF-4575180 was found to be effective in reducing ethanol consumption at $30 \mathrm{~min}$ post-dose. Although it is conceivable that shortly after $1 \mathrm{mg} / \mathrm{kg}$, the $C_{\mathrm{b}, \mathrm{u}}$ of PF-4575180 may be insufficient to produce a behavioral 
effect, it was surprising that the $1-\mathrm{mg} / \mathrm{kg}$ dose did show activity at later time points, ie, at $24 \mathrm{~h}$, when $C_{\mathrm{b}, \mathrm{u}}$ values are significantly lower than at $30 \mathrm{~min}$. Interestingly, a similar phenomenon was also observed for the other compounds that still displayed behavioral activity $24 \mathrm{~h}$ post-dose at much lower $C_{\mathrm{b}, \mathrm{u}}$ than after $30 \mathrm{~min}$. Further studies are required to examine possible underlying mechanisms, as this type of hysteresis could suggest an indirect exposure-response relationship. In that scenario, initial drug levels in the pharmacological relevant concentration range could trigger an $\alpha 3 \beta 4$ nAChR-mediated event that has longer-lasting downstream consequences, eg on mesolimbic dopamine. It is clear that the long-lasting effects of CP-601932 and varenicline in rats cannot be attributed to active metabolites, as these are not formed in vivo (Obach et al, 2006; Shaffer et al, 2009), but that possibility has not been investigated for PF-4575180. Finally, although PF-4575180 is more potent than CP-601932 in vitro, it is less efficacious in decreasing ethanol consumption in the animal model, because of lower $C_{\mathrm{b}, \mathrm{u}}$ that reduce in vivo potency. However, free $C_{\mathrm{b}, \mathrm{u}}$ of $\mathrm{CP}-601932$ decline much more slowly than that of PF-4575180, which may account, at least in part, for this apparent discrepancy. Although the correlation of in vitro binding affinities and behavioral potencies need to be better understood, a consistent finding is that both compounds selectively decrease ethanol and not sucrose consumption.

The present data on the $\alpha 3 \beta 4 \mathrm{nAChR}$ partial agonists CP-601932, PF-4575180, and varenicline, as well as previously published data on the selective $\alpha 3 \beta 4^{*} \mathrm{nAChR}$ desensitizing agent 18-methoxycoronaridine (18-MC) (Rezvani et al, 1997), suggest that effects on ethanolmediated behaviors are mediated via inhibition and/or activation of $\alpha 3 \beta 4^{*}$ nAChRs, but do not exclude a potential role of inhibition of $\alpha 4 \beta 2^{*} \mathrm{nAChRs}$, at least after CP-601932 and varenicline treatment. To explore this further, we showed that $\alpha 4 \beta 2^{*}$ nAChR antagonist, $\mathrm{DH} \beta \mathrm{E}$, which lacks activity at $\alpha 3 \beta 4^{*}$ nAChRs (Harvey et al, 1996) does not decrease ethanol consumption in long-term heavy drinking rats, further supporting the findings of other investigators in animals that consume smaller amounts of ethanol (Larsson et al, 2002; Le et al, 2000). In studies involving short-term drinking mice (10-15 days), varenicline's effect has been shown to be mediated by the $\alpha 4$ and not the $\beta 2$ or $\alpha 7$ subunit of the nAChR in genetically modified mice (Hendrickson et al, 2010; Kamens et al, 2010). It is important to note that our studies were conducted in animals with a longer drinking history of at least 8 weeks. PF-4575180 has good affinity for $\alpha 6 / 4 \beta 4$ nAChRs $\left(K_{\mathrm{i}}=45 \mathrm{nM}\right)$, but given the inability of the $\alpha 6^{*}$ selective $\alpha$ CtxPIA analogue to antagonize ethanol-induced locomotor stimulation and dopamine release (Jerlhag et al, 2006), it seems unlikely that the $\alpha 6$ subunit is involved in the effects of ethanol. The $\alpha 3$ subunit of the nAChR has been shown to be important for acute locomotor responses to ethanol in mice (Kamens et al, 2008). Taken together, with the at least 10 -fold higher affinity of CP-601932 and PF-4575180 for $\alpha 3 \beta 4$ than for $\alpha 6 / 4 \beta 4$ nAChRs, our data suggest that $\alpha 3 \beta 4^{*}$ nAChRs may have a predominant role in mediating ethanol-induced behaviors in long-term drinking animals.

The $\alpha 4 \beta 2^{*}$ nAChRs are one of the major subtypes in the brain and are expressed in the ventral tegmental area (VTA) and nucleus accumbens (NAcc) and have been shown to modulate dopamine release (Duvoisin et al, 1989; Gotti et al, 1997; Klink et al, 2001). In contrast, the $\alpha 3 \beta 4^{\star} \mathrm{nAChRs}$ are more highly expressed outside the VTA and NAcc in regions such as the medial habenula, nucleus interpeduncularis, dorsal medulla, and pineal gland (Fonck et al, 2009; Han et al, 2000; Quick et al, 1999; Wada et al, 1989; Zoli et al, 1998). The habenula complex has been shown to indirectly modulate dopamine release in the NAcc via the VTA (Matsumoto and Hikosaka, 2007; Ullsperger and von Cramon, 2003). We hypothesize that partial agonists at $\alpha 3 \beta 4^{*}$ nAChRs decrease ethanol self-administration and consumption by indirectly modulating the mesolimbic dopaminergic system. Data on 18-MC, the only other compound that has been reported to have activity at $\alpha 3 \beta 4^{\star} \mathrm{nAChRs}$ and to reduce ethanol-seeking (Rezvani et al, 1997), as well as nicotine-seeking behavior in rats (Glick et al, 2002), are in agreement with this hypothesis. 18 -MC has no effect at $\alpha 4 \beta 2 \mathrm{nAChRs}$ and binds with micromolar affinities to other receptors (Glick et al, 2000), but is thought to act by stabilizing the desensitized state of the $\alpha 3 \beta 4 \mathrm{nAChR}$ with $\mathrm{IC}_{50}$ values ranging from 0.75 to $0.90 \mu \mathrm{M}$ (Pace et al, 2004). CP-601932 and PF-4571580 are also expected to inhibit $\alpha 3 \beta 4 \mathrm{nAChRs}$, but are more potent with $\mathrm{IC}_{50}$ values of $0.1-0.3 \mu \mathrm{M}$, while their partial agonist properties will also permit some receptor activation.

Ligands with affinity for $\alpha 3^{*}$ nAChRs have generally been avoided in drug discovery programs, as $\alpha 3^{*}$ nAChRs have a role in ganglionic transmission and modulation of this receptor is believed to underlie nicotinic adverse effects, such as constipation, urinary retention, hypertension, and mydriasis. However, a growing number of studies have indicated the presence of $\mathrm{nAChRs}$ that contain subunits in numerous configurations with accessory subunits that would not only change the pharmacology and kinetics of nAChRs but also differ in expression in the CNS and periphery (see review (Gotti et al, 2007)). Indeed, CP601932 has been examined in a clinical trial as a potential smoking cessation aid and did not show side effects indicative of ganglion blocking effects. CP-601932 has been shown after oral administration to be well absorbed, to have a long half-life, to undergo renal and metabolic clearance equally, and to have extensive brain penetration in rats, which are key attributes when considering new medicinal agents (Shaffer et al, 2009). Hence, we hypothesize that CP-601932 could present a pharmacotherapeutic option to reduce ethanol consumption via central $\alpha 3 \beta 4^{*}$ nAChRs and suggest that a clinical CP-601932 study in subjects with AUDS could evaluate its efficacy and potential benefits.

In summary, our data suggest that $\alpha 3 \beta 4^{\star} \mathrm{nAChRs}$ may be important therapeutic target for the treatment of AUDs. Furthermore, as $\alpha 4 \beta 2^{*}$ nAChRs have been strongly implicated in nicotine dependence and as CP-601932 is equipotent at $\alpha 3 \beta 4$ and $\alpha 4 \beta 2 \mathrm{nAChRs,} \mathrm{this} \mathrm{compound}$ has also the potential to reduce smoking in alcoholics with co-morbid nicotine dependence.

\section{ACKNOWLEDGEMENTS}

We thank Brian Medina, Haley Pierson, Jade Bito-Onon, and Rui Li (Gallo Research Institute), and Shari L DeNinno, 
Alka Shrikhande, Sarah M Osgood, Mary MacDougall, Laura McDowell, and JianHua Liu (Pfizer Global Research and Development) for excellent technical assistance. This work was supported by funding from the NIH, 1R01AA017924-01 (to SEB), DOD, \#W81XWH-08-1-0016 (to SEB), and the State of California for Medical Research on Alcohol and Substance Abuse through the University of California, San Francisco (to SEB). The Foundation BLANCEFLOR Boncompagni-Ludovisi née Bildt (to PS), the Sweden-America Foundation (to PS), and Insamlingsstiftelsen Hjärnfonden/The Swedish Brain Foundation (to PS).

\section{DISCLOSURE}

JWC, RSH, CLS, JL, and HR are employees of Pfizer, the manufacturer of varenicline. The other authors declare that there are no personal financial holdings that could be perceived as constituting a potential conflict of interest. SEB has received financial support for research on an unrelated clinical study on varenicline, but has not received compensation from any individual or corporate entity over the past 3 years for research or professional service.

\section{REFERENCES}

Balcombe JP, Barnard ND, Sandusky C (2004). Laboratory routines cause animal stress. Contemp Top Lab Anim Sci 43: 42-51.

Blomqvist O, Soderpalm B, Engel JA (1992). Ethanol-induced locomotor activity: involvement of central nicotinic acetylcholine receptors? Brain Res Bull 29: 173-178.

Cahill K, Stead L, Lancaster T (2009). A preliminary benefit-risk assessment of varenicline in smoking cessation. Drug Saf 32: 119-135.

Chatterjee S, Bartlett SE (2010). Neuronal nicotinic acetylcholine receptors as pharmacotherapeutic targets for the treatment of alcohol use disorders. CNS Neurol Disord Drug Targets 9: 60-76.

Chen X, Chen J, Williamson VS, An SS, Hettema JM, Aggen SH et al (2009). Variants in nicotinic acetylcholine receptors alpha5 and alpha3 increase risks to nicotine dependence. Am J Med Genet B Neuropsychiatr Genet 150B: 926-933.

Cippitelli A, Karlsson C, Shaw JL, Thorsell A, Gehlert DR, Heilig M (2010). Suppression of alcohol self-administration and reinstatement of alcohol seeking by melanin-concentrating hormone receptor 1 (MCH1-R) antagonism in Wistar rats. Psychopharmacology (Berl) 211: 367-375.

Coe JW, Brooks PR, Vetelino MG, Wirtz MC, Arnold EP, Huang $J$ et al (2005a). Varenicline: an alpha4beta2 nicotinic receptor partial agonist for smoking cessation. J Med Chem 48: 3474-3477.

Coe JW, Brooks PR, Wirtz MC, Bashore CG, Bianco KE, Vetelino MG et al (2005b). 3,5-Bicyclic aryl piperidines: a novel class of alpha4beta2 neuronal nicotinic receptor partial agonists for smoking cessation. Bioorg Med Chem Lett 15: 4889-4897.

Dani JA, Harris RA (2005). Nicotine addiction and comorbidity with alcohol abuse and mental illness. Nat Neurosci 8: 1465-1470.

Davis TJ, de Fiebre CM (2006). Alcohol's actions on neuronal nicotinic acetylcholine receptors. Alcohol Res Health 29: 179-185.

de Fiebre CM, Collins AC (1992). Classical genetic analyses of responses to nicotine and ethanol in crosses derived from longand short-sleep mice. J Pharmacol Exp Ther 261: 173-180.

Duvoisin RM, Deneris ES, Patrick J, Heinemann S (1989). The functional diversity of the neuronal nicotinic acetylcholine receptors is increased by a novel subunit: beta 4 . Neuron 3: 487-496.

Fonck C, Nashmi R, Salas R, Zhou C, Huang Q, De Biasi M et al (2009). Demonstration of functional alpha4-containing nicotinic receptors in the medial habenula. Neuropharmacology 56: 247-253.

Freathy RM, Ring SM, Shields B, Galobardes B, Knight B, Weedon $\mathrm{MN}$ et al (2009). A common genetic variant in the $15 \mathrm{q} 24$ nicotinic acetylcholine receptor gene cluster (CHRNA5CHRNA3-CHRNB4) is associated with a reduced ability of women to quit smoking in pregnancy. Hum Mol Genet 18: 2922-2927.

Glick SD, Maisonneuve IM, Kitchen BA (2002). Modulation of nicotine self-administration in rats by combination therapy with agents blocking alpha 3 beta 4 nicotinic receptors. Eur J Pharmacol 448: 185-191.

Glick SD, Maisonneuve IM, Szumlinski KK (2000). 18-Methoxycoronaridine (18-MC) and ibogaine: comparison of antiaddictive efficacy, toxicity, and mechanisms of action. Ann N Y Acad Sci 914: 369-386.

Goodwin FL, Amit Z (1998). Do taste factors contribute to the mediation of ethanol intake? Ethanol and saccharinquinine intake in three rat strains. Alcohol Clin Exp Res 22: 837-844.

Gotti C, Fornasari D, Clementi F (1997). Human neuronal nicotinic receptors. Prog Neurobiol 53: 199-237.

Gotti C, Moretti M, Gaimarri A, Zanardi A, Clementi F, Zoli M (2007). Heterogeneity and complexity of native brain nicotinic receptors. Biochem Pharmacol 74: 1102-1111.

Gotti C, Zoli M, Clementi F (2006). Brain nicotinic acetylcholine receptors: native subtypes and their relevance. Trends Pharmacol Sci 27: 482-491.

Han ZY, Le Novere N, Zoli M, Hill Jr JA, Champtiaux N, Changeux JP (2000). Localization of $n A C h R$ subunit mRNAs in the brain of Macaca mulatta. Eur J Neurosci 12: 3664-3674.

Harvey SC, Maddox FN, Luetje CW (1996). Multiple determinants of dihydro-beta-erythroidine sensitivity on rat neuronal nicotinic receptor alpha subunits. J Neurochem 67: 1953-1959.

Hendrickson LM, Zhao-Shea R, Pang X, Gardner PD, Tapper AR (2010). Activation of alpha $4^{\star}$ nAChRs is necessary and sufficient for varenicline-induced reduction of alcohol consumption. J Neurosci 30: 10169-10176.

Hogg RC, Bertrand D (2004). Nicotinic acetylcholine receptors as drug targets. Curr Drug Targets CNS Neurol Disord 3: 123-130.

Jerlhag E, Grotli M, Luthman K, Svensson L, Engel JA (2006). Role of the subunit composition of central nicotinic acetylcholine receptors for the stimulatory and dopamine-enhancing effects of ethanol. Alcohol Alcohol 41: 486-493.

Joslyn G, Brush G, Robertson M, Smith TL, Kalmijn J, Schuckit M et al (2008). Chromosome 15q25.1 genetic markers associated with level of response to alcohol in humans. Proc Natl Acad Sci USA 105: 20368-20373.

Kamens HM, Andersen J, Picciotto MR (2010). Modulation of ethanol consumption by genetic and pharmacological manipulation of nicotinic acetylcholine receptors in mice. Psychopharmacology 208: 613-626.

Kamens HM, McKinnon CS, Li N, Helms ML, Belknap JK, Phillips TJ (2008). The alpha3 subunit of the nicotinic acetylcholine receptor is a candidate gene for ethanol stimulation. Genes Brain Behav 6: 600-609.

Klink R, de Kerchove d'Exaerde A, Zoli M, Changeux JP (2001). Molecular and physiological diversity of nicotinic acetylcholine receptors in the midbrain dopaminergic nuclei. J Neurosci 21: 1452-1463.

Larsson A, Svensson L, Soderpalm B, Engel JA (2002). Role of different nicotinic acetylcholine receptors in mediating behavioral and neurochemical effects of ethanol in mice. Alcohol 28: 157-167. 
Le AD, Corrigall WA, Harding JW, Juzytsch W, Li TK (2000). Involvement of nicotinic receptors in alcohol self-administration. Alcohol Clin Exp Res 24: 155-163.

Lowe III JA, DeNinno SL, Coe JW, Zhang L, Mente S, Hurst RS et al (2010). A novel series of [3.2.1] azabicyclic biaryl ethers as alpha3beta4 and alpha6/4beta4 nicotinic receptor agonists. Bioorg Med Chem Lett 20: 4749-4752.

Matsumoto M, Hikosaka O (2007). Lateral habenula as a source of negative reward signals in dopamine neurons. Nature 447: 1111-1115.

McKee SA, Harrison EL, O'Malley SS, Krishnan-Sarin S, Shi J, Tetrault JM et al (2009). Varenicline reduces alcohol selfadministration in heavy-drinking smokers. Biol Psychiatry 66: 185-190.

Moss HB, Chen CM, Yi HY (2007). Subtypes of alcohol dependence in a nationally representative sample. Drug Alcohol Depend 91: 149-158.

Nelson ME, Kuryatov A, Choi CH, Zhou Y, Lindstrom J (2003). Alternate stoichiometries of alpha4beta2 nicotinic acetylcholine receptors. Mol Pharmacol 63: 332-341.

Obach RS, Reed-Hagen AE, Krueger SS, Obach BJ, O'Connell TN, Zandi KS et al (2006). Metabolism and disposition of varenicline, a selective alpha4beta2 acetylcholine receptor partial agonist, in vivo and in vitro. Drug Metab Dispos 34: 121-130.

Ochoa EL, Chattopadhyay A, McNamee MG (1989). Desensitization of the nicotinic acetylcholine receptor: molecular mechanisms and effect of modulators. Cell Mol Neurobiol 9: 141-178.

Pace CJ, Glick SD, Maisonneuve IM, He LW, Jokiel PA, Kuehne ME et al (2004). Novel iboga alkaloid congeners block nicotinic receptors and reduce drug self-administration. Eur J Pharmacol 492: $159-167$.

Picciotto MR, Zoli M, Rimondini R, Lena C, Marubio LM, Pich EM et al (1998). Acetylcholine receptors containing the beta2 subunit are involved in the reinforcing properties of nicotine. Nature 391: 173-177.

Quick MW, Ceballos RM, Kasten M, McIntosh JM, Lester RA (1999). Alpha3beta4 subunit-containing nicotinic receptors dominate function in rat medial habenula neurons. Neuropharmacology 38: 769-783.

Rezvani AH, Overstreet DH, Yang Y, Maisonneuve IM, Bandarage UK, Kuehne ME et al (1997). Attenuation of alcohol consumption by a novel nontoxic ibogaine analogue (18-methoxycoronaridine) in alcohol-preferring rats. Pharmacol Biochem Behav 58: 615-619.

Rollema H, Chambers LK, Coe JW, Glowa J, Hurst RS, Lebel LA et al (2007). Pharmacological profile of the alpha4beta2 nicotinic acetylcholine receptor partial agonist varenicline, an effective smoking cessation aid. Neuropharmacology 52: 985-994.

Rollema H, Hajos M, Seymour PA, Kozak R, Majchrzak MJ, Guanowsky V et al (2009). Preclinical pharmacology of the alpha4beta2 nAChR partial agonist varenicline related to effects on reward, mood and cognition. Biochem Pharmacol 78: 813-824.

Rollema H, Shrikhande A, Ward KM, Tingley III FD, Coe JW, O'Neill BT et al (2010). Pre-clinical properties of the alpha4beta2 nicotinic acetylcholine receptor partial agonists varenicline, cytisine and dianicline translate to clinical efficacy for nicotine dependence. Br J Pharmacol 160: 334-345.

Saccone NL, Wang JC, Breslau N, Johnson EO, Hatsukami D, Saccone SF et al (2009). The CHRNA5-CHRNA3-CHRNB4 nicotinic receptor subunit gene cluster affects risk for nicotine dependence in African-Americans and in European-Americans. Cancer Res 69: 6848-6856.

Schlaepfer IR, Hoft NR, Collins AC, Corley RP, Hewitt JK, Hopfer CJ et al (2008). The CHRNA5/A3/B4 gene cluster variability as an important determinant of early alcohol and tobacco initiation in young adults. Biol Psychiatry 63: 1039-1046.

Shaffer CL, Ryder TF, Venkatakrishnan K, Henne IK, O'Connell TN (2009). Biotransformation of an alpha4beta2 nicotinic acetylcholine receptor partial agonist at Sprague-Dawley rats and the dispositional characterization of its n-carbamoyl glucuronide metabolit. Drug Metab Dispos 37: 1480-1489.

Simms JA, Steensland P, Medina B, Abernathy KE, Chandler LJ, Wise $\mathrm{R}$ et al (2008). Intermittent access to $20 \%$ ethanol induces high ethanol consumption in Long-Evans and Wistar rats. Alcohol Clin Exp Res 32: 1816-1823.

Steensland P, Simms JA, Holgate J, Richards JK, Bartlett SE (2007). Varenicline, an alpha4beta2 nicotinic acetylcholine receptor partial agonist, selectively decreases ethanol consumption and seeking. Proc Natl Acad Sci USA 104: 12518-12523.

Tapper AR, McKinney SL, Nashmi R, Schwarz J, Deshpande P, Labarca C et al (2004). Nicotine activation of alpha4* receptors: sufficient for reward, tolerance, and sensitization. Science 306: 1029-1032.

Ullsperger M, von Cramon DY (2003). Error monitoring using external feedback: specific roles of the habenular complex, the reward system, and the cingulate motor area revealed by functional magnetic resonance imaging. J Neurosci 23: 4308-4314.

Wada E, Wada K, Boulter J, Deneris E, Heinemann S, Patrick J et al (1989). Distribution of alpha 2, alpha 3, alpha 4, and beta 2 neuronal nicotinic receptor subunit mRNAs in the central nervous system: a hybridization histochemical study in the rat. J Comp Neurol 284: 314-335.

Wang JC, Grucza R, Cruchaga C, Hinrichs AL, Bertelsen S, Budde JP et al (2009). Genetic variation in the CHRNA5 gene affects mRNA levels and is associated with risk for alcohol dependence. Mol Psychiatry 14: 501-510.

Wise RA (1973). Voluntary ethanol intake in rats following exposure to ethanol on various schedules. Psychopharmacologia 29: $203-210$.

Wishka DG, Walker DP, Yates KM, Reitz SC, Jia S, Myers JK et al (2006). Discovery of $\mathrm{N}-[(3 \mathrm{R})-1$-azabicyclo[2.2.2]oct-3-yl]furo [2,3-c]pyridine-5-carboxamide, an agonist of the alpha7 nicotinic acetylcholine receptor, for the potential treatment of cognitive deficits in schizophrenia: synthesis and structureactivity relationship. J Med Chem 49: 4425-4436.

Zhou Y, Nelson ME, Kuryatov A, Choi C, Cooper J, Lindstrom J (2003). Human alpha4beta2 acetylcholine receptors formed from linked subunits. J Neurosci 23: 9004-9015.

Zoli M, Lena C, Picciotto MR, Changeux JP (1998). Identification of four classes of brain nicotinic receptors using beta2 mutant mice. J Neurosci 18: 4461-4472.

Supplementary Information accompanies the paper on the Neuropsychopharmacology website (http://www.nature.com/npp) 